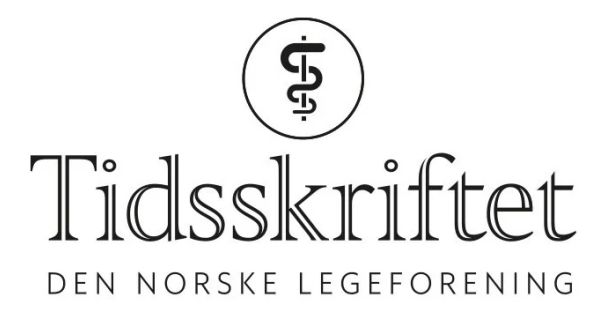

\title{
Resultatbasert finansiering av medisinsk forskning
}

KRONIKK

\section{ANE JOHANNESSEN}

Email: ane.johannessen@helse-bergen.no

Regionalt kompetansesenter for klinisk forskning

Haukeland universitetssykehus

5021 Bergen

\section{NILS ERIK GILHUS}

Institutt for klinisk medisin

Universitetet i Bergen

og

Nevrologisk avdeling

Haukeland universitetssykehus

Prinsippet om resultatbasert finansiering av forskning over statsbudsjettet for både helseforetak og universitet er ukjent for mange, men av stor praktisk betydning for å oppnå ressurser til videre forskning. Nasjonalt publiseringsutvalg for medisinske fag ble opprettet i 2007. Vi ønsker på utvalgets vegne å informere om resultatbasert finansiering og om nivåinndelingen av publikasjoner innen medisinske fag og prinsippene som ligger til grunn for denne. 


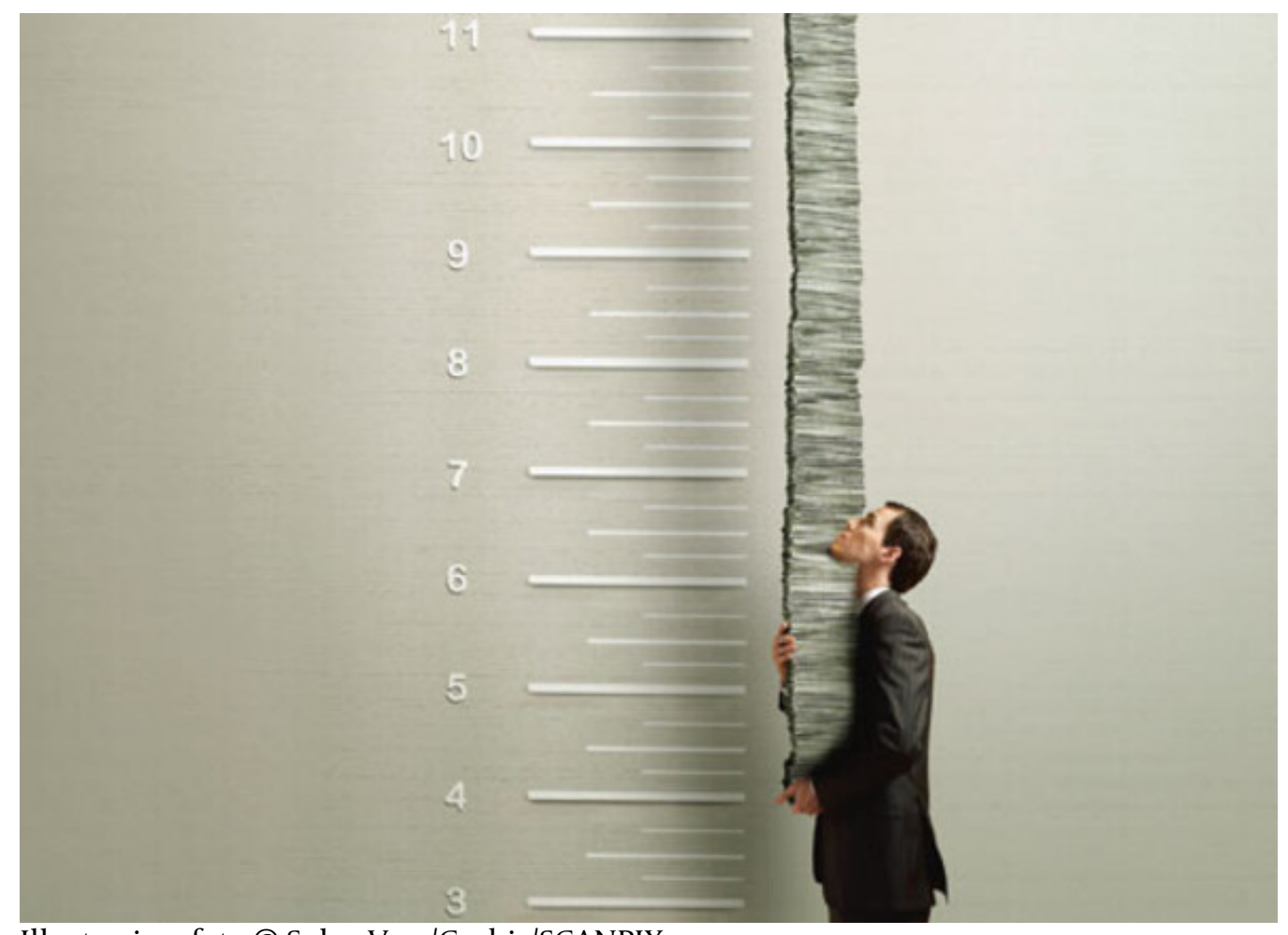

Illustrasjonsfoto @ Solus-Veer/Corbis/SCANPIX

Nasjonalt publiseringsutvalg for medisinske fag omfatter universitetene, helseforetakene og høyskolene. Hovedoppgaven er å utarbeide og ivareta en nivå- og faginndeling av publikasjonskanaler for medisinske fag samt arbeide for publisering som fremmer god medisinsk forskning. Tilsvarende nasjonale utvalg (fagråd) finnes for alle vitenskapelige områder. Utvalgene rapporterer til et felles publiseringsutvalg som Universitets- og høyskolerådet har opprettet på oppdrag fra Kunnskapsdepartementet.

Medisinsk forskning anses som samfunnsmessig viktig og er en høyt prioritert aktivitet. Slik forskning er ressurskrevende. Det er derfor rimelig at samfunnet ønsker en tilfredsstillende oversikt over forskningsresultater og et system som stimulerer til god forskning. Et hensiktsmessig system er viktig for dem som finansierer og organiserer forskning og for forskerne selv. Et forskningsprosjekt er ikke fullført før resultatene er offentliggjort i fagfellevurderte publikasjoner. Registrering av publikasjoner er derfor en god indikator på forskningsaktivitet og benyttes i økende grad som grunnlag for finansiering. Dette gjelder både for universiteter og helseforetak. Utfordringen er å etablere et system som belønner god forskning, som anses som rettferdig, som forstås og som kan anvendes uten for stor ressursbruk.

\section{Vitenskapelige publikasjoner}

Det er to hovedutfordringer ved resultatmåling av vitenskapelig produksjon: Hvordan definere og telle vitenskapelige publikasjoner, og hvordan gjøre dette slik at man samtidig stimulerer til kvalitet i forskningen? Fordi det dreier seg om et stort antall publikasjoner som ikke kan vurderes hver for seg, trenger man automatiserte, bibliometriske metoder. På det medisinske fagfeltet er disse heldigvis lett tilgjengelig. Et vitenskapelig arbeid vurderes ut fra publikasjonskanal, dvs. hvor det er publisert. Artikler kategoriseres ut fra tidsskrift, bøker ut fra forlag. De aller fleste medisinske artikler kan hentes fra tidsskriftsindekser som ISI og PubMed. For forskere med universitetstilknytning legges øvrige vitenskapelige publikasjoner manuelt inn i databasen FRIDA.

Et utvalg oppnevnt av Kunnskapsdepartementet har nylig lagt frem forslag til en felles nasjonal database for alle vitenskapelige publikasjoner, kalt Norsk Vitenskapsindeks. Hittil har universitetene i sin registrering benyttet FRIDA, helseforetakene har kun benyttet ISI 
og PubMed. Publikasjonskanalen (tidsskriftet) må være autorisert. Kravet er at artiklene i det aktuelle tidsskriftet bringer ny viten og er fagfellevurderte. Kanalen må i tillegg ikke utelukkende ha lokale forfattere, tidsskriftet må derfor i praksis være på minst nasjonalt nivå. Når det gjelder bøker, må forlaget være godkjent som utgiver av vitenskapelig litteratur. En database som oppfyller disse kriteriene, vil gi en god oversikt over antall vitenskapelige publikasjoner, som er ett av målene på forskningsresultat.

Publikasjonskvalitet er mer utfordrende å måle. Det er imidlertid helt nødvendig med et slikt mål. Måling kun av antall vil kunne lede til oppsplitting og duplisering av forskningsresultater og arbeider av lavere kvalitet. Et hovedmål for forskning er det motsatte, nemlig å oppnå enkeltpublikasjoner som holder internasjonalt nivå og som oppfattes å være grunnleggende på fagfeltet. Enkeltpublikasjoner kan vurderes skjønnsmessig av fagfeller og bibliometrisk ut fra antall ganger de blir sitert av andre. I et nasjonalt system som omfatter alle publikasjoner, er det imidlertid praktisk nødvendig å benytte publikasjonskanalen som kvalitetsindikator (1) .

Impaktfaktor regnes ofte som det etablerte kvalitetsmålet for medisinske tidsskrifter (므). Mer presist er denne faktoren et direkte mål på hvor hyppig artikler i tidsskriftet gjennomsnittlig blir sitert (ramme 1). Tidsskriftene med høyest impaktfaktor har mest prestisje. Men impaktfaktor har svakheter som kvalitetsmål $(3,4$.). Tidsskrifter for ulike fagfelter er vanskelige å sammenlikne, og tidsskrifter med mange oversiktsartikler kommer alltid best ut. Det er videre en fare for at impaktfaktor i praksis måler popularitet heller enn kvalitet, siden det ikke er gitt at en artikkel som siteres hyppig, er representativ for kvaliteten på alle artikler som publiseres i det tidsskriftet. I norske fagmiljøer er det imidlertid gjennomgående stor enighet om hvilke tidsskrifter som er de ledende internasjonalt, og hvor det er særlig attraktivt å publisere sine beste forskningsresultater. Det er disse tidsskriftene som er løftet opp til nivå 2.

\section{Ramme 1}

\section{Hvordan beregnes impaktfaktor?}

- Impaktfaktor bestemmes ut fra hvor mange siteringer artiklene som er publisert i det aktuelle tidsskriftet de foregående to år har resultert i dette året

- Antallet siteringer deles på antall siterbare artikler publisert i tidsskriftet de to årene

- Hvis alle artikler publisert i et tidsskrift i 2003 og 2004 blir sitert én gang i 2005, blir impaktfaktoren for dette tidsskriftet i 2006 1,0

I kvalitetsvurderingen av tidsskrifter har det vært diskutert både hvor mange kategorier et system skal operere med, hvor stor andel av tidsskriftene som bør være i hver kategori, og hvor stor forskjell det skal være på vektingen av publikasjoner i kategoriene. Det har vært ulikheter mellom universitetene og helseforetakene når det gjelder disse punktene, men med ett lite unntak er inndelingen av tidsskriftene nå samordnet. I universitetssystemet er det to kvalitetsnivåer, helseforetakene opererer med et ekstra toppnivå i tillegg til de to universitetsnivåene (5) (ramme 2).

\section{Ramme 2}

\section{Inndeling av tidsskrifter i kvalitetsnivåer}

- Nivå 2 er det beste og representerer omkring $20 \%$ av det som publiseres innen et fagfelt på verdensbasis. Siden noen tidsskrifter har svært store årganger med mange artikler, mens andre har få artikler i løpet av et år, betyr dette at det ikke er $20 \%$ av 
tidsskriftene innen et fagfelt som omfattes av nivå 2, men derimot $20 \%$ av artiklene på fagfeltet. Helseforetakene har i tillegg et toppnivå $2 \mathrm{~A}$, som består av de aller gjeveste generelle tidsskriftene: Nature, Nature Medicine, Science, New England Journal of Medicine, The Lancet og Proceedings of the National Academy of Sciences USA

- Nivå 1 omfatter det resterende $80 \%$ av det som publiseres gjennom autoriserte kanaler innen et fagfelt. Kravet for å være autorisert kanal er at artiklene i det aktuelle tidsskriftet bringer ny viten og er fagfellevurderte

- Artikler oppnår publikasjonspoeng ut fra kvalitetsnivå. Nivå 1 gir ett poeng, nivå 2 tre poeng og nivå $2 \mathrm{~A}$ (kun helseforetakene) gir ti publikasjonspoeng (5)

Det er publikasjonen som telles og som gir poeng. For å kunne benyttes som resultatmål og grunnlag for finansiering må den forankres i institusjon eller person. Forfatteradresser er markøren som benyttes. Det er de adressene som artikkelforfatterne har benyttet som inngår i registreringen, dvs. at artikkelens publikasjonspoeng deles på antall oppførte adresser. Rekkefølgen spiller ingen rolle. En artikkel med tre publikasjonspoeng (nivå 2) og fire forfattere som alle har oppgitt to adresser, gir o,375 publikasjonspoeng til hver av adressene (institusjonene). En institusjon med en adresse som blir gjenkjent av det databaserte systemet som en norsk virksomhet som inngår i ordningen (universitet, helseforetak), vil få kreditt. Det er dermed avgjørende at forfatterne setter opp helt korrekt og utvetydig adresse. Fors $\emptyset \mathrm{k}$ på å slå sammen en universitetsadresse og en helseforetaksadresse kan lede til at ingen av dem blir gjenkjent og ingen får kreditt. Hver enkelt adresse må altså anføres korrekt og separat. Alle relevante institusjoner har klare regler for navnsetting på norsk og engelsk.

\section{Nasjonalt publiseringsutvalg}

Nasjonalt publiseringsutvalg for medisinske fag ønsker å spille en rolle for alle aspekter vedrørende registrering av publikasjoner og samordning mellom universiteter og helseforetak samt i vurderingen av publikasjoner i et resultatbasert finansieringssystem. Publiseringsutvalget består av én representant fra hver av de fire regionale samarbeidsutvalgene (universiteter, helseforetak), med observatører fra Universitets- og høyskolerådet, Norsk institutt for studier av innovasjon, forskning og utdanning (NIFU STEP) og Norsk samfunnsvitenskapelig datatjeneste. Sekretariatet er lagt til Det medisinskodontologiske fakultet ved Universitetet i Bergen.

Medisin er av utvalget delt inn i 21 ulike fagfelter. Disse er biomedisin, helsevitenskap, anestesi, dermatologi, endokrinologi, gastroenterologi, geriatri, gynekologi/obstetrikk, hematologi, hjerte/kar/luftveier, infeksjon, kirurgi, nefrologi, nevrologi, onkologi, pediatri, psykiatri, radiologi, revmatologi, øre-nese-hals og øye. Hvert av disse fagfeltene har en komité med én representant fra hver av regionene. Oppgaven er først og fremst å foreslå tidsskrifter til nivå 2. Nivå 2 skal omfatte tidsskrifter som publiserer $20 \%$ av alt som publiseres innen fagfeltet. Fagfeltenes størrelse har dermed ingen betydning for hvor trangt nåløyet er for nivå 2. Et større fagfelt vil få med flere tidsskrifter.

Inndelingen av fagfelt har vært mye diskutert. Det er gode argumenter for både å splitte og samle. Det er ikke hensiktsmessig å forandre fagfeltsinndelingen til stadighet, det vil vanskeliggjøre sammenlikninger over tid. Biomedisin er den klart største gruppen, helsevitenskap er også omfattende. Sistnevnte er heterogen og med til dels lite sammenfall når det gjelder ledende tidsskrifter. Helsevitenskap vil derfor sannsynligvis bli splittet. Fagfelter med et lavt antall publikasjonspoeng vil kunne bli slått sammen.

Norsk samfunnsvitenskapelig datatjeneste registrerer nye kanaler som fyller kravene til vitenskapelig publisering. Dette gjelder også tidsskrifter med fritt tilgjengelige artikler (open access). Disse kan også foreslås til nivå 2. Institusjoner og enkeltpersoner kan søke 
om å få registrert nye tidsskrifter og forlag. Dersom Norsk samfunnsvitenskapelig datatjeneste er i tvil om hvorvidt kravene er oppfylt, vil publiseringsutvalget vurdere søknaden.

Utvelgelse av nivå 2-tidsskrifter skal diskuteres grundig og er ikke alltid lett. I praksis er tidsskriftenes anseelse og gjennomslagskraft fordelt over en jevn skala uten trinn. I utvelgelsen av de ledende innen et fagfelt bør impaktfaktor ha en førende innflytelse. Men fagkomiteen bør i tillegg gjøre en strategisk vurdering av hvor man ønsker at de beste norske forskningsresultatene skal publiseres. Under ellers nokså like betingelser har noen valgt å prioritere et europeisk fremfor et amerikansk tidsskrift. Dette fordi forskere tenderer til å sitere arbeider fra egen verdensdel, noe som bidrar til nordamerikanske tidsskrifters gjennomgående høye impaktfaktorer. Tidsskrifter som domineres av oversiktsartikler, anbefales ikke som nivå 2, selv om de ofte har svært høy impaktfaktor. Slike artikler vil som regel bli sitert hyppigere enn originalartikler, uten at de nødvendigvis har høyere kvalitet.

Enkelte faggrupper har ytret ønske om å prioritere skandinaviske tidsskrifter for nivå 2, kanskje for å øke oppnådd nivå 2-andel for norske publikasjoner. Det nasjonale publiseringsutvalget vil bare godta slike tidsskrifter dersom impaktfaktoren er omtrent like høy som for de øvrige nivå 2-tidsskriftene på feltet, og høyere enn for dem i nivå 1gruppen. Oppdaterte lister over nivå 2- og nivå 1-tidsskrifter ligger på Internett (므). For 2007 var andelen medisinske publikasjoner på nivå 2 på 21,5\%, dvs. slik den skal være. Det var imidlertid en viss variasjon mellom fagfeltene, som må justeres.

Det har vært hevdet at nåværende ordning med å splitte en artikkels publikasjonspoeng på alle forfatteradresser svekker heller enn stimulerer til samarbeid mellom nasjonale og internasjonale institusjoner. Et slikt samarbeid er definitivt ønskelig. I et felles system som dekker alle typer forskning, ikke bare medisin, er imidlertid dette gjeldende regel. Det nasjonale publiseringsutvalget har diskutert om det likevel er mulig å stimulere internasjonalt samarbeid bedre. Vi har foreslått å gi alle publikasjoner med ikke-norsk forfatteradresse en merverdifaktor på 0,3 samt sette nedre uttelling for én enkelt forfatteradresse til o,1 per publikasjon.

Et hovedpunkt for det nasjonale publiseringsutvalget i medisin har vært å arbeide for et felles system for publikasjonsregistrering og kreditering innenfor universiteter og helseforetak. Dette arbeidet er nå godt i gang. Komiteen for hvert enkelt fagfelt har et ansvar for å formidle sine vurderinger innad i egne miljøer samt motta innspill vedrørende endringer. Komiteene vil etter hvert ganske sikkert også vurdere omfang og kvalitet av nasjonal publisering innen eget felt. Hvordan er fordelingen mellom nivå 1 og nivå 2? Er vi bedre eller dårligere enn gjennomsnittet i verden, kommer vi over $20 \%$ ? Øker vi antall oppnådde publikasjonspoeng, og øker eget fagfelt mer eller mindre enn dem vi vil sammenlikne oss med? Nettopp slik bruk vil oppfylle en hovedhensikt, nemlig å bruke systemet som stimulans til mer og bedre vitenskapelig publisering.

\section{Ikke-medisinske fag}

Resultatbasert finansiering og krav til dokumentasjon av vitenskapelig publisering gjelder alle fagfelter, ikke bare medisin. Dette har vært en utfordring for systemet siden publiseringstradisjon og ønsket publikasjonsform varierer fra fag til fag. Dessuten er de fleste fag innen samfunnsvitenskap og humaniora svakt dekket i databaser som ISI eller PubMed, og da er det vanskelig å beregne impaktfaktor og verdensproduksjonen av artikler på fagfeltet. Men prinsippet om at nivå 2 skal omfatte omkring $20 \%$ av alt som publiseres, samt kravene til nivå 1, gjelder likt over hele linjen. De aller fleste andre fag har i lang tid hatt fagråd, som også har behandlet publiseringsdokumentasjon. Medisin hadde ikke et naturlig organ, og dermed ble det nasjonale publiseringsutvalget opprettet. 
For enkelte medisinske fagfelter vil en samordning med ikke-medisinske felter være nødvendig. Dette gjelder f.eks. biologi i forhold til biomedisin. Universitets- og høyskolerådet har en samlende og koordinerende funksjon i dette arbeidet.

\section{Økonomiske konsekvenser}

En klar hensikt med bedre publikasjons- og forskningsregistrering har vært å benytte resultatene som grunnlag for finansiering. Dette gjelder både Kunnskapsdepartementets finansiering av universitetene og Helse- og omsorgsdepartementets finansiering av helseforetakene (7,,$\underline{8})$. Begge har forskning som en av hovedoppgavene. For helseforetakene utgjør den resultatbaserte komponenten $60 \%$ av samlet bevilgning til forskning fra departementet. Universitetene har i mindre grad resultatbaserte budsjetter, men midlene som der går til forskning, utgjør en større del av de samlede inntektene. For begge typer institusjoner har dermed forskningsresultater målt som publikasjonspoeng en vesentlig og direkte innflytelse på budsjettet. Totalbeløpet bevilget fra departementene påvirkes ikke av antall publikasjonspoeng. Det betyr at det er relativt resultat, sett i forhold til alle de øvrige universiteter/helseforetak, som avgjør bevilgningen. Mange oppfatter det som svært uheldig - til tross for økt antall publikasjonspoeng kan man få lavere bevilgning hvis andre har $ø$ kt mer. Staten har imidlertid valgt omfordeling fremfor premiering.

De $\emptyset$ konomiske konsekvensene for institusjonene er klare. Det varierer imidlertid i hvilken grad omfordelingen blir videreført på enhetsnivå - fakultet og institutt, avdeling og seksjon. Forskergrupper og enkeltforskere ser nok sjelden en direkte pekuniær belønning. Samtidig bør et effektivt incentivsystem være merkbart for flest mulig av dem som kan påvirke forsknings- og publikasjonsresultater. Dette er en utfordring for institusjonene. En direkte kobling av publikasjonspoeng og finansiering vil ofte være urettferdig på detaljnivå. For å avdempe svingninger vil de fleste velge å benytte aggregerte publikasjonsdata fra for eksempel tre år.

Selv om finansieringen basert på forskningsresultater er viktig både for universiteter og helseforetak, må det understrekes at disse midlene bare utgjør en svært liten del av institusjonenes totale budsjetter. Dette avspeiler at både institusjonene og personene som utfører arbeidet har mange oppgaver utover å publisere forskningsresultater. Dessuten har både universiteter og helseforetak et ansvar for å drive frem forskning i alle relevante miljøer, ikke utelukkende i dem med aller best publikasjonsresultat.

\section{Publikasjonsregistrering som incitament}

Modellen med nivåinndeling av publikasjonskanaler, registrering av publikasjoner og resultatbasert finansiering av forskning kan stimulere til økt oppmerksomhet omkring forskningskvalitet på flere nivåer. Når institusjonene vektlegger forskning ut fra bl.a. $\emptyset$ konomiske hensyn, kan dette i seg selv fungere som et incitament også for enkeltforskere. Systemet får en normativ virkning, hvor forskerne strekker seg etter å utgi arbeider av høy kvalitet heller enn å publisere mye på bekostning av kvaliteten.

\section{Konklusjon}

Hovedmålet med publikasjonsregistrering og resultatbasert finansiering er å fremme god forskning. Hensiktsmessig registrering og kvalitetsvurdering er enklere i medisin enn på mange andre fagfelter. Aktører i medisinsk forskning har gjennomgående akseptert både resultatkrav og konkurranse om finansiering. Utfordringen er å lage et system som faktisk fremmer ønsket forskningsaktivitet. Samtidig må det være praktisk gjennomførbart, og 
prinsippene må være forstått og i hovedsak godtatt av dem det angår. Nasjonalt publiseringsutvalg for medisinske fag er en av aktørene. Vi ønsker å arbeide bredt sammen med de enkelte fagmiljøene for å fremme både forskningskvalitet og publikasjonskvalitet.

\section{Oppgitte interessekonflikter:}

Ingen

\section{LITTERATUR}

1. Sivertsen G. Måling av forskningsaktiviteten ved helseforetakene: vitenskapelige artikler og doktorgrader som resultatindikatorer. NIFU-skriftserie nr.1/2003. Oslo: Norsk institutt for studier av forskning og utdanning, 2003. www.nifustep.no/content/download/1007/9958/file/skriftserie12003.pdf (4.1.2009).

2. Garfield E. Journal impact factor: a brief review. CMAJ 1999; 161: 979-80. www.cmaj.ca/cgi/content/full/161/8/979 (4.1.2009).

3. Seglen PO. Why the impact factor of journals should not be used for evaluating research. BMJ 1997; 314: 498-502. www.bmj.com/cgi/content/full/314/7079/497 (4.1.2009).

4. Rossner M, Van Epps H, Hill E. Show me the data. J Cell Biol 2007; 179: 1091-2. http://jcb.rupress.org/cgi/content/full/179/6/1091 (4.1.2009).

5. Helse- og omsorgsdepartementet. Resultatbasert målesystem for forskning. www.regjeringen.no/nb/dep/hod/tema/Helseforskning/resultatbasert-malesystem-forforskning.html?id=226724 (2.11.2008).

6. Norsk samfunnsvitenskapelig datatjeneste (NSD). Register over publiseringskanaler. http://dbh.nsd.uib.no/kanaler (2.11.2008).

7. St.prp. nr.1 (2001-2002). Oversikt over budsjettforslaget fra Kyrkje, utdannings- og forskningsdepartementet. Programkategori o76o og 0770.

www.regjeringen.no/nb/dep/kd/dok/regpubl/stprp/20012002/Stprp-nr-1-2001-2002-.html?id=433979 (2.11.2008).

8. St.meld. nr. 5(2003-2004). Inntektssystem for spesialisthelsetjenesten. Kapittel 6. www.regjeringen.no/nb/dep/hod/dok/regpubl/stmeld/20032004/Stmeld-nr-5-2003-2004-html? $\mathrm{id}=197375$ (2.11.2008).

Publisert: 26. mars 2009. Tidsskr Nor Legeforen. DOI: 10.4045/tidsskr.08.0362 Manuskriptet ble mottatt 10.10. 2008 og godkjent 8.1. 2009. Medisinsk redaktør Erlend Hem. (C) Tidsskrift for Den norske legeforening 2023. Lastet ned fra tidsskriftet.no 26. april 2023. 